\title{
"Will I ever connect with the students?": Online Teaching and the Pedagogy of Care
}

\author{
Ellen Rose, University of New Brunswick, Fredericton, Canada \\ Email: erose@unb.ca \\ Catherine Adams, University of Alberta, Edmonton, Canada \\ Email:cathy.adams@ualberta.ca
}

\begin{abstract}
Since Noddings (1984/2003) first made a case for acknowledging care as a core element and value in pedagogical relationships, research on care in classrooms has flourished. While research confirms the importance of a supportive environment for the success of the online student, we know little about how online instructors experience care-for their students and for themselves. This paper offers a phenomenological exploration of care as it is experienced in online postsecondary instructors' interactions and relations with their students. The stories shared by four instructors highlight the 24/7 demands for care that are felt by the online instructor, and the tension that consequently arises between care for the students and self-care.
\end{abstract}

\section{Introduction}

I was online, working on a particular course, when an instant message pops up on the screen: "Oh hi, professor, I don't understand this assignment and I'm freaking out. I really need you to answer me."1

Instructors who teach online may recognize this moment from their own experience: a student, spotting that her instructor is logged on, sends a desperate plea for help, hoping for an immediate response. Or, checking her course first thing in the morning, an instructor discovers several emails from a student, all posted in the wee hours, requesting her technical assistance to submit a file. Unlike their "offline" colleagues, online teachers are finding themselves increasingly on call and available to be interrupted via email, texts, and "pop-ups." How do the responsibilities to students and the expectations of care differ for online teachers from instructors who teach only in brick-and-mortar classrooms? What might an ethic of online pedagogical care entail? Can the "disembodied" online student evoke the same sense of care that may be experienced by the teacher in face-to-face situations?

Heidegger (1962) tells us that our being-in-the-world is essentially relational, or "beingwith": we are immersed in and called into authentic being by care for our own existence (Sorge), and our lives are structured and made meaningful by Fürsorge — solicitude or concern for others,

\footnotetext{
${ }^{1}$ Italicized quotes represent material collected during interviews with university instructors and/or via solicited written experiential descriptions as part of a Social Sciences and Humanities Research Council-funded research project. All names are pseudonyms. Participant interviews adhered to the guidelines set by the Tri-Council Policy Statement: Ethical Conduct for Research Involving Humans.
} 
actively looking after and providing for someone who needs help (p. 158). Can we extrapolate from Heidegger's notion of being-in-the-world to say that, for online university instructors, being-in-an-online course is also a matter of entering into a "being-with" relationship of care and solicitude in which instructors and those with whom they form caring relationships are revealed? Or are online teachers' relations with students more akin to Heidegger's (1977) notion of the technological attitude, in which the world and the beings in it increasingly show up as resources, available to be ordered and used in ways that will fulfill instrumental intentions and desires?

Noddings' (1984/2003) seminal work identifies the "ethic of care" as central to the practice of teaching. She characterizes the experience of caring in terms of "engrossment" and "motivational displacement." Engrossment involves "an open, nonselective receptivity to the cared-for," a willingness to "really hear, see, or feel what the other tries to convey," while motivational displacement is "the sense that our motive energy is flowing toward others...I want to respond in a way that furthers the other's purpose or project” (Noddings, 2005, pp. 15-16). Deacon (2012) insists that "creating a context of care is...even more pressing in online classes" than in face-to-face instruction (p. 6). Should we then assume that "Nodding's theories...can help in supporting the process of learning online and the development of the community" (Crosta \& McConnell, 2005, p. 22)? Or is it rather, as Dreyfus (2009) suggests, that caring relationships are contingent upon the immediacy of intercorporality? Do online instructors experience challenges in attaining empathy and attunement to students who may be experienced solely as "typed bodies" (Kazan, 2007, p. 253, emphasis in original), composed of diction, grammar, and syntax rather than corporeal substance?

Since Noddings (1984/2003) first made the case for acknowledging care as a core element and value in pedagogical relationships between teachers and students, research and writing on care in classrooms has flourished. Many studies (e.g., Bevis \& Watson, 2000; Goldstein, 2002; Vogt, 2002) seek to elaborate what care entails within the context of teaching. Others (e.g., Cassidy \& Bates, 2005; Mercado, 1993) are concerned with showing the connection between relations of care and students' ability to flourish in academic environments. Still others (e.g., Barber, 2002; McKenzie \& Blenkinsop, 2006) explore the extent to which care informs teachers' professional identity and practice. However, while research has shown the importance of a supportive environment for the success of the online learner, a review of the literature reveals very little when it comes to the nature and role of care in online teaching and learning. As Sitzman and Leners (2006) observe, "Online interactions are different, and the question of whether these interactions engender an environment of caring is unanswered” (p. 254).

Furthermore, the few studies that do inquire into the nature of care in online teaching and learning tend to focus on the perceptions and opinions of the cared-for (the students) rather than the prereflective or lived experiences of the ones-caring (the instructors). For example, Sitzman and Leners' (2006) qualitative study sought graduate nursing students' perspectives on factors that made them feel cared for in an online setting, such as frequent, prompt feedback and multiple contact opportunities. In a replication of the study with undergraduate students, Leners and Sitzman (2006) found similar results. Marx's (2011) investigation of how caring is manifested for graduate students in online courses also suggests that students perceive caring through such factors as timely feedback and positive, personal comments. Hall's (2010) quantitative study of the relationship between instructor caring and students' persistence in online and face-to-face courses found that the learning environment did not play a role in students' perceptions of their instructors as caring: "students in online environments felt cared for just as well if not better than students in traditional classrooms” (p. 57). However, Kim and 
Schallert's (2011) analysis of transcripts of online dialogues and interviews with teacher and students paints a less homogeneous picture, suggesting that the experience of feeling cared for, or not, is unique for each student, "influenced by the complex associations among expectations and beliefs of the students and the teacher, and their interpretations of each other's words" (p. 1066).

Van Manen (2002) observes that scholarly theorizing about caring runs the risk of "degrading a profoundly human phenomenon... when our understanding gets cut off from the ways caring is actually experienced" (p. 263). Thus, while the studies mentioned above enrich our understanding of the extent to which students feel cared for in online interactions, they give little insight into what it is like for an instructor to care for his or her students online. McShane (2006) gestures in this direction with her qualitative study of academic identity and online teaching. Based on interviews with twelve university instructors making the shift to online instruction, she concludes provocatively that "the carer finds it difficult to care online” (p. 202):

In sum, the carer as online facilitator cannot convey empathy, trust, passion and emotion online, and teacher-student relationships break down due to the inability to convey responsiveness and reciprocity....Stated clearly, my thesis is that online education facilitates "the end of obligated relations to others." (p. 203)

As asynchronous, web-based, enterprise-scale systems increasingly augment, extend, and replace conventional classroom environments in post-secondary education, it behooves us to enlarge our understanding of what it means to teach and learn, and to care, in an online environment. The purpose of this phenomenological inquiry is to learn more about the extent to which university instructors who meet and interact with learners within the bounds of a computer-based learning management system experience and enact care and solicitude, engrossment and motivational displacement, in their relations with their students.

\section{Phenomenology of Practice}

In this paper, we offer a phenomenological exploration of care as it may reveal itself in online postsecondary instructors' correspondences and relations with their students. Phenomenology aims to reconnect with the everyday lifeworld — "the world of our immediately lived experience, prior to all our thoughts about it” (Abram, 1996, p. 40) - in an effort to recapture the prereflective, invariant aspects of an experience. Although we draw upon the work of Heidegger, Noddings, and other theorists, the starting point for this, as for all phenomenological inquiry, is not theory but rather the everyday, practical engagements of instructors and their students online. In particular, this paper is grounded in lived experience descriptions - recollected moments from teachers teaching online-gathered through phenomenological interviews with online university instructors. In this paper, we confine our reflections to anecdotes selected from interviews with three instructors, and a journal entry by another, in order to investigate one thematic that emerged from a larger phenomenological study with twenty instructors at two universities. These four lived experience descriptions were selected to offer a range of experiences situated at various points, beginning to end, in the delivery of online courses.

With a nod to Heidegger, van Manen (1990) insists that phenomenological research "is decidedly unmethodological in a purely prescriptive or technocratic sense” (p. 3), and is "more a carefully cultivated thoughtfulness than a technique” (p. 131). And yet, he adds, his 
"phenomenology of practice” (van Manen, 2007) has “a certain methodos-a way” (1990, p. 29). In brief, that "way" entails reading and re-reading lived experience descriptions "with fresh eyes" (Barritt, et al, 1984, p. 6) that are attentive to the prereflective or existential dimensions of the phenomenon of interest; conducting thematic analyses of the experiential descriptions aimed at discerning and giving voice to the essence, or eidos, of the experience-the unique qualities "that make a phenomenon what it is and without which the phenomenon could not be what it is" (van Manen, 1990, p. 106, emphasis in original); and, finally, reflecting on the phenomenon in such a way that the reader may reawaken to "the lived quality and significance of the experience in a fuller, deeper manner” (van Manen, 1990, p. 10). Such a phenomenology of practice is undertaken to provide glimpses of the unique existential structure and patterns of meaning of instructors' experiences of caring in an online course.

Below we offer our phenomenological reflections on the four selected online teaching moments. The paper concludes with a return to the questions with which we began, as well as others that emerge from our consideration of the teachers' anecdotes as they relate to the experience and manifestation of pedagogical care in an online environment.

\section{The Tyranny of Availability}

Just three days into my online course and I'm being bombarded with emails from the students: "I can't find what I'm looking for," "I don't understand what I'm supposed to do," "I don't know how to join a group," "how to participate in group discussions," "I'm thinking of dropping the course." I open yet another of these frantic messages and begin to compose a reply: "As it says in the course outline," I type, aware that my frustration and growing irritation are quite evident in this terse line, but finding myself unable to moderate my response. The fall sunshine makes a mirror of my computer screen: I can see the birch outside my window, its leaves just beginning to turn yellow and dancing in the warm breeze. Sitting here at my computer, trying to compose a response (as well as compose myself!), I feel confined and claustrophobic within this room, and yet, at the same time, totally at sea within this online course. I've taught it so many times face-to-face, with great success, but despite all my efforts, all the hours I spent designing this learning environment, the same course transferred online has become a vast, unfriendly void in which it now seems unlikely that I will ever connect with the students. At this point, after so many volleys of hostile email messages, I'm not even sure that I want to.

Before email, before online courses, college students might raise their hand during a lecture, linger anxiously after class, stop by during office hours, or perhaps telephone for an appointment to pose a question or discuss a concern with their professor. Failing the opportunity for such a meeting, students would necessarily be thrown back on their own resources, to work things out for themselves. Back then, student-teacher interactions and communications were defined and constrained by the limits of scheduled timetables, office hours, and the mutual availability of teacher and student. Today, the Internet has opened the possibility of teachers being available to students $24 / 7$.

To be technologically "available” means, according to Borgmann (1984), that a particular commodity - here access to one's professor — “has been rendered instantaneous, ubiquitous, safe, and easy” (p. 40). Such instantaneous availability disburdens the consumer-here the student- 
of the real effort previously required to procure this service or product. Campus email, smartphones, online learning systems and computing infrastructures now afford students easy, commodious, 24/7 access to their teachers. Of course, this does not mean that the teacher is actually "on call" every moment of the day and night. Or does it? To what extent do students expect that immediate access implies an immediate response, and to what extent do instructors internalize that expectation? Are our understandings of what pedagogical care and responsibility entail readjusted when teaching and learning take place in an environment where the instructor is potentially within reach anytime, anywhere?

Logging in to her email, the online teacher experiences her technologically enabled availability to students as a frantic bombardment. A cacophony of student voices confronts her from all directions at once. What might "connect[ing] with" and caring for students mean to an instructor who feels under siege and compelled to sort through and field each of a litany of little technical issues ("I don't know how to join a group") shuffled in between bigger decision concerns ("I'm thinking of dropping the course")? Big or small, urgent or trivial, each message is presented in the same textual format. One concern might be best addressed in a private, face-toface meeting, another with a brief tutorial to the whole class, yet another requiring a referral to the Tech Help Desk. Yet none of these options may be available to the online teacher.

In the midst of such technology enabled bombardment, the online teacher may struggle to feel a devoted concern for her students. As Noddings (1984/2003) observes, "when we become overburdened...our caring turns into 'cares and burdens"” (p. 18). While this negotiation between caring and carrying the weight of too many cares is hardly unique to the online teacher, it may be especially intensified for instructors teaching in an "always on" online environment.

\section{The Demanding Student}

I was online, working on a particular course, when this instant message pops up on the screen: "Oh hi, professor, I don't understand this assignment and I'm freaking out. I really need you to answer me." My immediate response was-give me a second. So, I decided to take a few minutes and go ahead and finish what I was doing before I answered her. But you know what? She's having a bit of a panic attack and it's not good. So, within about 30 seconds of making that decision, I reversed it and quickly responded with an instant message. Then I went back to my task but I kept looking at the left side of the screen to see if she was still logged on. No, she's still in, okay. I waited for her response. I started drumming my fingers on table, now beginning to feel somewhat resentful-I actually had an appointment to get to. So I decided: "Okay, I can't wait any longer." I was just in the midst of typing to her, "I have to leave so please email me with what you think," when she instant messaged me back, saying it's fine and it's all good and if she has any more problems she'll email me and thank you so much for your time and your attention. And I thought, "Thank god!"

As discussed above, research shows that, for students, one of the primary indicators of care in online instruction is prompt feedback. Tarlow (1996) confirms that an important aspect of caring is "being there" for the cared-for, which means that the one-caring is accessible, approachable, and responsive. But when the cared-for is not co-present, what exactly does "being there" mean?

In a face-to-face situation, a teacher cannot pretend to be absent from her classroom or office when approached by a student who is "freaking out," nor can she defer her response. The 
student is in crisis and the teacher must be wholly present within that moment; her facial expressions, gestures, and tone must embody a caring response to the student's needs. However, in an online environment, the instructor may be "there," logged onto the learning management system and engaged in some technical fiddling with the content or structures of the online course, but still not available to her students. In fact, the capability to conceal one's presence, and defer caring, may be built into the parameters of the learning management system, allowing the teacher to choose to set her online status to invisible. Thus, unlike a teacher in a face-to-face situation, the teacher is able to make a conscious and deliberate choice about when she will respond, and she may choose to be not there - to feign absence through her unresponsiveness.

In the 24/7 world of online teaching and learning, such a decision may seem justified. The face-to-face teacher is available to students only during class and office hours: outside those prescheduled timeframes, the teacher can count on not being bombarded by needy students, not having her work interrupted. But this is not the case for the online teacher, who may experience a fundamental conflict between caring for students and caring for the self. What are the teachers' responsibilities to herself? Should caring for students come at the expense of her own health and well-being?

The obligations of the online teacher include not only care for the students but for the course itself: the technological artifact, with its seemingly endless demands for her attention. For the face-to-face teacher, class preparation is an activity that, by definition, takes place prior to the class, in preparation for classroom interactions with the students. But for the online instructor, preparation is ongoing, a ceaseless tinkering to deal with technical issues and ensure that discussions and learning activities run smoothly. Are the demands of the students experienced differently from the demands of the course, or are they somehow conflated in the teacher's experience, all part of a single onrush of need confronting her? Which takes priority? If attention to a student's needs are deferred, only a single student is affected, but if the issues attending the online course are not resolved promptly-if inappropriate discussion posts are not removed, if work-arounds are not found to deal with technological glitches - then general chaos may ensue.

According to Noddings (1984/2003), individuals who are over-extended may not experience care as a natural impulse. In such cases, decisions to respond to students in a caring way are activated by what Noddings calls the "ethical ideal": the teacher's "best picture" of herself "caring and being cared for" (p. 80). The ethical ideal evokes a strong desire to do what is necessary in order to sustain relationality and calls forth what Noddings calls the "I must": that is, if I am to continue to believe in myself as a caring individual, then I must respond to this student. The student who sent the panicked instant message in the above anecdote would likely say that the teacher's behavior in this situation manifested an ethic of care: she responded promptly and helpfully, and eventually the student gratefully thanked her teacher for her time and attention. But to what extent is caring in the online course experienced as an authentic, pre-reflective impulse, and to what extent is it experienced as a desire to have a "teacherly attitude," and to behave accordingly, in ways that will sustain relationality?

\section{Cold, Dark, and Quiet}

It's late at night and I am in the living room; my kids have gone to bed and my husband is downstairs watching TV and I'm upstairs, and it's quiet. All the kids are sleeping and it's just the light in the living room on upstairs and I can just hear the background TV noise downstairs. And so it's just me. It's quiet, it's dark, it's late, it's winter. The window is 
right beside me; it's a huge picture window, and it is black. And I worked all day, and I'm online at night: check e-mails, answer the questions, check the papers, and I'm popping in and out of the discussion. It's the same kind of routine every night.

For the online instructor, the duties of reading and responding to discussion posts may be experienced as a continuation of an already busy day into the evening and night. Even when the online course is part of the teacher's course load, she is likely to defer much of the timeconsuming work of reading and responding to posts to the evening, after a full day of interacting face-to-face with students and colleagues. Thus, her duties as an online instructor may not take place in the office but in the comfortable surround of her own home, an environment that embodies and is created by her own caring relations with her family.

The after-dinner hours can also be busy for the face-to-face teacher, a good time for class preparation or marking. Although these activities are solitary, the students' faces are imaginatively present to the teacher as she writes comments on assignments and plans class activities. As a caring teacher, she ensures that her comments are constructive rather than hurtful, and that her class plans are appropriate and relevant. Her tact is connected, linguistically and experientially, to her "contact” with embodied students (van Manen, 1991).

The online teacher takes similar care in reading and crafting responses to her students' discussion posts; for, in a way, the posts are her students, the textual traces by which she knows them, rather than the articulations of students who are also known as embodied beings. And yet the students are not there in the posts: reading and responding, the teacher is alone-perhaps even more alone than the face-to-face teacher who is able to counter her exhaustion and solitude by evoking the faces of her students as she works. For the online teacher, there are no faces, and very little in the posts to distinguish them, to make one student stand out as in some way different from, or more "known," than the others. Sitting before the screen, she experiences her online students as email messages, questions, the occasional crisis - entities (rather than beings) she must deal with in a routine fashion before moving away from the computer and into the warmth and light of her "real" life. And so the activity of reading and responding may become not a communication or a caring, (con)tactful interaction but a solitary late-night chore.

Reflecting on his experiences as a face-to-face teacher, Gergen (2009) writes, "I find it difficult to think of my actions in the classroom independent from the students I teach....What takes place in the classroom is our achievement together” (p. 241). But for the online teacher, sitting before her computer at night, online teaching is experienced as an intensely solitary occupation, devoid of the warmth that comes from caring and being cared for. She has no sense of being in the learning management system, of sharing that space with her virtual students. And although she is performing as a caring teacher-responding promptly to messages and questions, guiding discussions - this performance does not necessarily entail or require felt care. Another instructor articulates the disjunction between care as a natural, unthinking response and her actual experience of care and solicitude in online teaching and learning environments in this way: "When I am online, I work hard on maintaining a warm, confident voice, creating a presence that is welcoming, unthreatening, and helpful. I'm always deeply aware, in a way I'm not in a face-to-face situation, of how I am 'coming across' to others...It feels so false; even though I like to think that's exactly who I am, I still feel like I'm putting on a mask.”

As in the previous anecdote, this instructor seems to be experiencing a tension between her ethical ideal — a self-perception of herself as a caring individual — and the burdens created by a learning structure that places unreasonable demands upon her to be "present" and attentive long 
after the workday is over. To what extent does caring, in such cases, become a matter of doing what needs to be done for the other, in a functional, routinized, and minimalistic way, as opposed to actually experiencing feelings of engrossment and solicitude? Can such behaviour actually be regarded as a manifestation of an ethic of care?

\section{Out There in Cyberspace}

At the end of a course, I had just finished marking, when I got word that one of my students, "Bev," had died. He had dropped dead at school on the last day of classes. Now, what bothered me was I thought Bev was a woman all the way through, and I thought, oh, isn't that awful-here I am teaching a course with other human beings and I didn't even know. About six weeks later, I got an email from another student in the course, "Rob," who had been a friend of Bev's. Rob said that he wanted me to know that on the day before Bev died, he had told Rob that he felt badly about an email he had sent me, that might have come across as rude, and Rob also wanted me to know that what we were doing in the course had really put Bev's self esteem way back up. This made me realize that the only way I had to relate to that man (who I didn't even realize was a man) was through his posting and my responding, and I thought about how a marked paper and what I could put in writing could have such an impact on someone who dropped dead the next day. Now, Bev's e-mail to me wasn't bad. But he had worried about it so much, and that bothered me because I didn't ever see his face, I never knew him as a real person outside of the context of the course, and I think he would have realized if he saw my face that whatever he put in the e-mail, if he'd said it to me, wouldn't have bothered me. He would have seen that and not worried about it. But it was sad that out there in cyberspace he didn't know, he couldn't see me.

We have all experienced the visceral recoil upon seeing someone fall, the instant, empathetic response to another person's pain, even if the person is a stranger. To what extent is caring similarly intercorporeal, dependent upon co-presence and a visual connection with the other? Can we experience feelings of care and solicitude for someone we have never seen, someone who is "out there in cyberspace”? According to Levinas (1996), face-to-face encounters give rise to an inescapable sense of ethical responsibility for the other: "a face imposes itself on me without my being able to be deaf to its call or to forget it...” (p. 54). Noddings (1983/2004) similarly suggests that our caring impulse is activated by the addressive or vocative appeal of those who are "proximate...under whose gaze I fall” (p. 113). But online interactions are inherently faceless; indeed, online instruction is often characterized as not face-to-face. If a visual, face-to-face connection prefigures care, then what is the nature of the connection enabled by the learning management systems that typically structure online learning experiences?

Of course, while faces are by definition part of the experience of face-to-face teaching and learning, not all of the faces will be known or knowable, or even proximate. The instructor of a class of hundreds will tend to see not individual students but a sea of faces with unreadable expressions. However, from this sea, she may seize upon a face or two-ones that are familiar, engaged, or attractive-as a focal point for her lectures and the basis of forging an empathetic connection with the class as a whole.

The online instructor is similarly tethered to a sense of face as a basis for relationality, prereflectively cobbling together who each student is, what he or she looks like, based on 
tenuous textual clues, small profile images which may or may not represent the person (some students choose photos of their pets or pop culture figures), and even the student's name. The resulting visualizations are very likely to be incorrect. When confronted with a reality that differs markedly from the imagined other, the teacher may experience a shock-similar to the discombobulating surprise that attends meeting an email correspondent for the first time, and discovering that one's imaginings about the other's appearance were simply incorrect.

Such a revelation may be experienced as a failure of care; the teacher may be "bothered" by her inability to get to know the student "as a real person," beyond the boundaries of the online course. Such botherment can be seen as symptomatic of the inevitable struggles of a caring teacher to meet her own expectations for engrossment and solicitude in an environment lacking the vital face-to-face connections that support the formation of caring relationships with her students.

\section{The Pedagogy of Care in Online Environments}

Modern communications technology has the ability to remove many of the restrictions related to physical distance from our social life. Yet distance is not only a material or geographical matter; it is also a social and ethical one.

(Miller 2012, p. 280)

Care, Noddings insists, manifests itself within relationships, which is to say that, for teachers in both online and face-to-face environments, the ethic of care is necessarily situated and constituted in everyday practice and experience. In this paper, we have asked, to what extent does the technological interface of the learning management system and its supporting online infrastructure support or disturb the care inhering in the pedagogical encounter? What does an ethic or pedagogy of care entail in online learning?

The experiential moments shared by these four instructors highlight the demanding quality of teaching online and of the learning management system itself, both of which invite and require constant tinkering and attention. Their stories suggest that this demanding quality sometimes imparts itself through messages from students, which may be experienced as a relentless bombardment from faceless entities rather than a means of connecting with other individuals. As teachers spend hours in the routinized labour of checking emails, reading discussion posts, and adjusting the parameters of the learning environment, do the faceless students and the burdensome technology somehow become enmeshed, so that the instructor's sense of care and responsibility for the students is displaced into care and responsibility for the system?

The anecdotes also highlight the tension between care for the students and self-care. When the learning environment is open for business 24/7, the instructor feels that she is always "on call," expected to respond promptly to communications from students. The 24/7 demands for care that are imposed upon the online instructor create a tension between her instincts to assist and attend to her students' needs and the imperatives of self-care. The online teacher is therefore involved in an ongoing process of negotiating, for herself, exactly what care in an online course entails. Must it go hand-in-hand with exhaustion and even burnout?

Finally, these anecdotes raise the question of the extent to which care in online courses becomes instrumental and performative, such that the teacher responds in ways she knows are 
"teacherly," even if she does not always experience feelings of "concernful solicitude" (Heidegger, 1962, p. 161) for her students. In Noddings' terms, to what extent do the structures within which online learning takes place hobble natural caring - the unthinking response-and activate ethical caring, in which instructors are guided not by an innate impulse but by a wish to live up to an ethical ideal? At what point might even that ethical ideal break down beneath the burdens of demanding students and troublesome technology?

Noddings (1984/2003) offers "the maintenance and enhancement of caring as the primary aim of education" (p. 174), and she further suggests that schools can be "deliberately designed to support caring and caring individuals” (p. 182). We might extend this mandate to learning management systems, but the flourishing of online instruction in postsecondary education, and most recently the rapid rise of the massive open online course (MOOC), suggests another aim has taken precedence over the development of caring relations between instructors and students. New questions therefore arise: As the integration of technology in higher education is increasingly driven by corporate models and goals, including economies of scale, what is the vocative call of the learning management systems that are developed to help meet these goals? As more and more of their relationships with students are mediated by online systems, will it become increasingly difficult for post-secondary instructors to experience care, or will the meaning of care morph to accommodate what is possible when instructional relationships develop within the bounds and capabilities of asynchronous online systems?

\section{References}

Abram, D. (1996). The spell of the sensuous: Perception and language in a more-than-human world. New York: Vintage Books.

Barber, T. (2002). A special duty of care: Exploring the narration and experience of teacher caring. British Journal of Sociology of Education, 23(3), 383-395.

Barritt, L., Beekman, T., Bleeker, H., \& Mulderij, K. (1984). Analyzing phenomenological descriptions. Phenomenology + Pedagogy, 2 (1), 1-17.

Bevis, E., \& Watson, J. (2000). Toward a caring curriculum. Boston, MA: Jones and Bartlett.

Borgmann, A. (1984). Technology and the character of contemporary life: A philosophical inquiry. Chicago: University of Chicago Press.

Cassidy, W., \& Bates, A. (2005). "Drop-outs” and "push-outs”: Finding hope in a school that actualizes the ethic of care. American Journal of Education, 112, 66-102.

Crosta, L., \& McConnell, D. (2005). Action research and tutoring in the online learning community: New implications for adult teaching and learning. In A. Gaskell \& A. Tait (Eds.), Reflective practice in open and distance learning: How do we improve? (pp. 19-25). Cambridge: The Open University. 
Deacon, A. (2012). Creating a context of care in the online classroom. Journal of Faculty Development, 26(1), 5-12.

Dreyfus, H.L. (2009). On the Internet ( $2^{\text {nd }}$ ed.). London: Routledge.

Gergen, K.J. (2009). Relational being: Beyond self and community. Oxford: Oxford University Press.

Goldstein, L.S. (2002). Reclaiming caring in teaching and teacher education. New York: Peter Lang.

Hall, L.R. (2010). Perceptions of faculty caring: Comparison of distance and traditional graduate nursing students. Unpublished doctoral dissertation. Terre Haute, Indiana: Indiana State University.

Heidegger, M. (1962). Being and time. (J. Macquarrie \& E. Robison, Trans.) San Francisco: Harper \& Row.

Heidegger, M. (1977). The question concerning technology and other essays. (W. Lovitt, Trans.). New York: Harper \& Row.

Kazan, T.S. (2007). Braving the body: Embodiment and (cyber-) texts. In J. Lockard \& M. Pegrum (Eds.), Brave new classrooms: Democratic education and the Internet (pp. 251269). New York: Peter Lang.

Kim, M, \& Schallart, D.L. (2011). Building caring relationships between a teacher and students in a teacher preparation program word-by-word, moment-by-moment. Teaching and Teacher Education, 27(7),1059-1067.

Leners, D. W., \& Sitzman, K. (2006). Graduate student perceptions: Feeling the passion of caring online. Nursing Education Perspectives, 27(6), 315-319.

Levinas, E. (1996). Basic philosophical writings. (A.T. Peperzak, S. Critchley, \& R. Bernasconi, Eds.). Bloomington: Indiana University Press.

Marx, G. (2011). Student and instructor perceptions of care in online graduate education: A mixed methods case study. Unpublished doctoral dissertation. Wichita, Kansas: Wichita State University.

McKenzie, M., \& Blenkinsop, S. (2006). An ethic of care and educational practice. Journal of Adventure Education and Outdoor Learning, 6(2), 91-105.

McShane, K. (2006). Technologies transforming academics: Academic identity and online teaching. Unpublished doctoral dissertation. Sydney, NSW: University of Technology. 
16 Rose \& Adams

Mercado, C.I. (1993). Caring as empowerment: School collaboration and community agency. Urban Review, 25(1), 79-104.

Miller, V. (2012). A crisis of presence: On-line culture and being in the world. Space and Polity, 16(3), 265-285.

Noddings, N. (2003). Caring: A feminine approach to ethics and moral education. Berkeley: University of California Press. (Original work published in 1984)

Noddings, N. (2005). The challenge to care in schools: An alternative approach to education. (2nd ed.). New York: Teachers College Press.

Sitzman, K., \& Leners, D.W. (2006). Student perceptions of caring in online baccalaureate education. Nursing Education Perspectives, 27(5), 254-259.

Stiegler, B. (2010). Taking care of youth and the generations (S. Barker, trans.). Stanford, CA: Stanford University Press.

Tarlow, B. (1996). Caring: A negotiated process that varies. In S. Gordon, P. Benner, \& N. Noddings (Eds.), Caregiving: Readings in knowledge, practice, ethics, and politics (pp. 5682). Philadelphia: University of Pennsylvania.

van Manen, M. (1990). Researching lived experience: Human science for an action sensitive pedagogy. New York: SUNY Press.

van Manen, M. (1991). The tact of teaching: The meaning of pedagogical thoughtfulness. New York: SUNY.

van Manen, M. (2002). Care-as-worry, or “don't worry, be happy.” Qualitative Health Research, 12(2), 262-278.

van Manen, M. (2007). Phenomenology of practice. Phenomenology \& Practice, 1(1), 11-30.

Vogt, F. (2002). A caring teacher: Explorations into primary school teachers’ professional identity and ethic of care. Gender and Education, 14(3), 251-264. 